IBAD, 2020; (6): 409-422

DOI: $10.21733 /$ ibad.665065

Özgün Araşttrma / Original Article

\title{
Türklerin Düğün Geleneklerinde Özgün Bir Tasarım: Gelin Habercisi Çengel
}

\section{Dr. Kevser Gürcan Akbaş ${ }^{\text {* }}$}

Geliș tarihi: 25.12. 2019

Kabul tarihi: 30.01 .2020

\section{Atıf bilgisi:}

IBAD Sosyal Bilimler Dergisi

Sayı: 6 Sayfa: 409-422

Yıl: 2020 Dönem: Kış

This article was checked by iThenticate. Similarity Index $02 \%$

Bu makalede araştırma ve yayın etiğine uyulmuştur.

${ }^{1}$ Mimar Sinan Güzel Sanatlar Üniversitesi, Türkiye, kevser.gurcan@msgsu.edu.tr ORCID ID 0003-2359-9143

\footnotetext{
* Sorumlu yazar
}

\section{öz}

Türk kültüründe evlenme önemli bir olgudur. Efsaneler, hikayeler, masallar, mitler gibi kültürel taşıyıcılığın etkin araçlarıyla aktarılagelenler, Türklerin tarihleri boyunca yaşadıkları coğrafyalarda sayısız çeșitlilikte evlenme ritüeli gerçekleştirdiklerini göstermektedir. Evlenme, toplumun en küçük yapı taşı olan aile oluşumunun başlangıcıdır. Doğum ve ölümün yanısıra insan ve toplum hayatını düzenleyen üç geçiş döneminden biridir. Kișinin özellikle de kadının bir taraftan diğer tarafa geçişini temsil etmektedir ve merkezinde gelin yer almaktadır. Türk inanışlarında "gelinin göçü" olarak da ifadesini bulan bu mitolojik yolculuğun özünde, gelinin baba ocağından yeni yurduna gidişin ötesinde yaradılış mitlerinden günümüze kültürel seyahatimizin şifreleri korunmaktadır. Bugün Anadolu düğün adetleri aynı geçmişte olduğu gibi sayısız çeşitliliğe ve anlam zenginliğine sahip uygulamalarla doludur. Bunların yanısıra uygulamasından vazgeçilmiş ancak sözlü ya da maddi kültürümüzde izleri bulunan bazı adetlerin de yok olmakla var olmak arasında kaldığı görülmektedir. Bu adetler, en azından literatüre geçirilmeyi ve kültür hazinemizde yer edinebilmeyi haketmektedirler. Bu adetlerden biri Gaziantep ve Malatya bölgesindeki köylerde hafizalarda kısmen muhafaza edilebilen; "gelin habercisi çengel” olarak adlandırılan bir unsurdur. Elimizde örneği bulunan Çengel; Türk mitolojisinin ana karakterlerinden biri olan -kadınların ve çocukların koruyucusu- "Umay Ana", olgusu üzerine yoğunlaşmaktadır. Türk inanç sistemine göre şekillenen evren tasarımı, dokuma, nakış, deniz kabukları, sedef düğmeler ve boncuk işleme gibi detaylarla hem geleneksel el sanatlarımıza 1şık tutan hem de tasarım sektörüne ilham verici nitelikte olan bir kültür ögemizdir. Gelin tarafindan genç bir çocuk bu haberciyi kafileden önce damat tarafina götürmekte ve gelini bekleyenler gelin alayının yola çıkmış olduğunu bu sayede anlamaktadır. Gelinin damadın evine gelmesinden sonra da kadınlar gelinin çeyizini, özellikle de Çengel'i görmek istemektedir. Çengel'in üzerinde bulunan malzemelerin ve uygulamaların niteliği gelinin ailesinin ekonomik durumunu ve gelinin becerisini göstermektedir. Düğünden sonra da bu Çengel, yeni gelin evinin en nadide köşesinde nazarlık olarak asili tutulmaktadir.

Anahtar Kelimeler: Türk Kültürü, Tasarım, İkonografi, Gelin Habercisi, Çengel. 


\section{An Authentic Design in Turkish Wedding Culture: Gelin Habercisi Çengel}

\section{Dr. Kevser Gürcan Akbaş ${ }^{1 *}$}

First received: 25.12 .2019

Accepted: 30. 01. 2020

\section{Citation:}

IBAD Journal of Social Sciences

Issue: 6

Pages: $409-422$

Year: 2020

Session: Winter

This article was checked by Turnitin. Similarity Index $02 \%$

1 Mimar Sinan Fine Arts University, Turkey, kevser.gurcan@msgsu.edu.tr ORCID ID 0003-2359-9143

* Corresponding Author

\begin{abstract}
Marriage is an important phenomenon in Turkish culture, carried out by effective means of cultural transport such as myths, legends, stories and tales. Throughout the history, Turkish people performed various marriage rituals in the geographies they lived. Marriage is the beginning of family formation, the smallest building block of society. It is one of the three transitional periods, which regulates a human and a society along birth and death. It represents the transition of the person, especially a woman, from one side to another centering the bride. At the core of this mythological journey, which is also referred as "gelinin göçü" in Turkish beliefs, is the codes of our cultural journey from the myths of creation to present day, beyond going from the father's home to another home. Today, Anatolian marriage rituals are filled with countless variety and richness of meaning, just like in the past. In addition to them, it is seen that some practices are abandoned yet the trace of them can be found in the oral or material culture. Those rituals at least deserve to be in the literature and gain a place in our cultural heritage. One of these rituals that is partially saved to the memories is something called "gelin habercisi/çengel" in villages around Gaziantep and Malatya. The Cengel example shown focuses on one of the prominent characters in the Turkish mythology - the protector of women and children- "Umay Ana". Universe design, which is shaped according to Turkish belief system, is a cultural element that sheds light on traditional handcrafts as well as inspiring the design sector with details such as weaving, embroidery, seashells, pearl buttons and beading. A young boy from the bride's side delivers this precursor before the convoy to groom's side and with that way those who wait for the bride will understand that the bridal procession is on its way. After the arrival of the bride to the groom's house, women would like to see the bride's dowery, especially the Çengel. The materials and the practices on the Çengel represent the bride's family' wealth and talent of the bride. This Çengel is hanged above in the most precious part of the new bride's house after the wedding as an amulet. In this article, Çengel/ Gelin Habercisi example found in Gaziantep was evaluated and interpreted according to its materials and iconography. In order to document, Çengel's technical drawing was made, all the drawings were photographed and an album was created. With this study, it is aimed to shed a light on our traditional values and to document them in order to bring it to the literature.
\end{abstract}

Keywords: Turkish Culture, Design, Iconography, Gelin Habercisi, Çengel, 


\section{GíRIŞs}

Halk kültürü, halkın yaşayış biçiminden oluşmaktadır ve özü gereği hareketlilik göstermektedir. Halk kültüründe yer edinebilen ve ulusal kalıt olarak adlandırılan ürünler belli bir zaman kesitinde oluşmakta ve gelenekler vasıtasıyla süregelmektedir. Böylece halk kültürü bireysel yaratıc1lık, gelenek ve icraları sayesinde şekillenerek varlığını devam ettiren bir olgu haline gelmektedir (Artun, 2005, s.59).

Geleneklerimiz, zaman içerisinde sürdürdüğümüz toplumsal uygulamalarımızın kurumsallaşmış örüntüsünü oluşturarak sosyo kültürel yapımızın DNA'larını teşkil etmektedir. Bu durum, binlerce yıllık zamana ve mesafeye rağmen Altaylar'da görülen damgaların, Anadoludaki halılar üzerinde de görünmesini açıklamaktadır (Aksoy, 2008, s.80). Bu nedenledir ki sanat eserlerini analiz ederken üretildiği sosyo kültürel yapının esas alınması gerekmektedir. Bir yapıtın anlamı o halkın zihniyetinde gizlidir. Sosyal grupların hafızası anlamına gelen zihniyet, bir topluluğun ortak bakışı, düşüncesi ve eylemi, kültürel kimliğinin ortak bileşenidir (Mucchielli, 1991, s.22).

Kültür unsurları belirli bir zaman periyodunun, fiziki ve sosyal ortamın çıktılarıdır ve etkenlerinin sayıları fazladır. Unsurları oluşturan motif, figür, sembol ve şekil gibi detaylar halkın kendisi tarafindan tasarlanmış olduğundan yalın duygu ve düşüncelerin aktarılması açısından oldukça önemlidir. Bu durum karşısında sosyo kültürel nesneleri anlamak, uygun metot ve tekniklerin kullanılmasının yanısıra etkili bir sezgi gücünü ve bilgi birikimini de gerektirmektedir (Aksoy, 2008, s.86). Bu yüzden bu alandaki çalışmalar, farklı disiplinlerin bir araya gelerek ortak akıl yürütmelerini esas almaktadır.

Semboller, sözden ve yazıdan daha etkili mesajlaşma araçlarıdır. İnanç ve düşüncenin somut olarak gün yüzüne çıkarılması, toplumla paylaşılması anlamına gelmektedir. Sembol dünyasında görünenin arkasında derin ve gizemli manalar yüklüdür. Bunu anlamak, toplumun ortak hafizası ve zihniyetine sahip diğer bireylerce kolay olabilir. Ancak bu, asırlar sonra yorumlamaya çalışan araştırmacılar için pek de kolay değildir. $\mathrm{Bu}$ yüzden bu ve benzeri etnografik unsurların çözümlenmesi tarihsel disiplin içerisinde yapılmalıdır.

Türk kültüründe önemli bir olguya karşılık gelen evlenme, toplumun en küçük yapı taşı olan aile oluşumunun başlangıcı olması ile birlikte, doğum ve ölümün yanısıra insan ve toplum hayatını düzenleyen üç geçiş döneminden biri olarak karşımıza çıkmaktadır ve özellikle kadının bir taraftan diğer tarafa geçişini temsil etmektedir.

Gennep'e göre evlilik sürecini kapsayan geçiş döneminde gerçekleştirilen ritüeller, bireyin yeni sosyal yaşamında yalnız olmadığına işaret etmektedir. Evlenme ritüellerindeki ana tema, bu geçişin toplum tarafindan tanınması ve kabul edilmesinin bir göstergesidir. Bu geçişin kendi içerisinde aşamaları bulunmaktadır. Birinci aşama "ayrılma"; bekarlıktan ve mevcut düzenden kopma yani söz yahut nişanlılık devresi, ikinci aşama "eşik"; bekarlık ve evlilik arasında gelinin ve damadın bu geçişin çeşitli olumsuz etkilerinden korunmasını sağlayan geçici süreç ve son olarak evlenme ile birlikte tekrar başa "kabul" aşamasına dönüştür. Bu durum, toplumda yeni bir aile olarak var olmanın ve kabul görmenin aşamasıdır. Gerçekleştirilen bu aşamalarda gelin ve damat statü değiştirme açısından eşit durumdadırlar (Gennep, 1960 s.61).

Evlenme ile ilgili gerçekleştirilen törenler, bünyesinde pekçok kültürel öge ile birlikte inanç unsurlarını da barındırmaktadır. Her ne kadar gelin ve damat için eşit bir statü değişikliği sağlasa da evlenme ritüellerinin merkezinde gelin yer almaktadır. Türk inanışlarında "gelinin göçü" olarak da ifadesini bulan bu mitolojik yolculuğun özünde gelinin baba ocağından yeni yurduna gidişin ötesinde yaradılış mitlerinden günümüze kültürel seyahatimizin de şifreleri korunmaktadır.

\section{TÜRK KÜLTÜRÜNDE EVLENME OLGUSU, DÜĞ̈UN ADETLERİ VE AİLE / OCAK KA VRAMI}

Anadolu kültüründe evlilik ritüelleri; öncesi, sırası ve sonrası uygulamaları içeren üç ana başlık altında incelenebilmektedir (Genç, 2018 s.55). Türk milleti hayatın her safhasında olduğu gibi, yeni bir hayatın başlangıcı olan düğün törenleri boyunca Tanrı kutunu yanında hissetmek istemektedir. Bunun için de bu üç aşamayı kapsayan, gelin seçimi ile başlayıp düğünün kırkı çıkıncaya kadar geçen süreçte mitolojik kökenli pek çok uygulama gerçekleştirilmektedir (Ergun, 2010 s. ). 
Gelinin baba ocağından damatla birlikte yaşayacağı eve doğru giderken gerçekleştirilen ritüeller modern zamanlarda bile en dikkat çekici olanlarıdır ve bölgelere göre farklılık gösterseler de en çok muhafaza edilen adetlerin de yine bunlar olduğu görülmektedir. Bu adetlerin başında; gelinin babası ya da erkek kardeşi tarafından gelinin beline evinden çıkmadan önce kırmızı kuşak bağlanması (bu durum pek çok bölgede gelinin bekaretinin bir göstergesi olarak kabul edilir), duvak üzerinin kırmızı tülbentle örtülmesi, güvey evine ulaşıldığında, geline at yahut arabadan inmeden önce düğüne katılanlar tarafindan para verilmesi, damat tarafindan (damadın anne yahut babası da olabilir) geline arsa, canlı hayvan, ağaç vb. hediye edilmesi, damadın evinin önünde/kapısında yeni kurulan aileye bolluk ve bereket getirmesi niyetiyle gelinin başından saçı saçılması (Emen, 2015, s.33) gelmektedir. Saçı, Türk kültüründe Orta Asya kökenli gelenekler arasında yer almaktadır. Bu saçı, boyların kendi ürettiği arpa, darı gibi kutsal kabul edilen nimetlerden oluşmaktadır (Gömeç 1998, s.44). Bu yüzden de manevi değeri yüksek bir ritüel olarak farklı içeriklerle de olsa günümüzde hala devam ettirilmektedir.

Baba evinden yeni yuvasına gidişin gelinin mitolojik göçü olarak kabul edilmesi nedeniyle, gidilen mesafenin kısa olması durumunda bile dolaşılarak (yol uzatılarak) gidilmesi oldukça dikkat çekicidir ve destanlarda da yer verilen bir konudur (Aydemir 2013, s.639). Çengel'in üzerindeki kompozisyonda da karşılığının görülmesi nedeniyle bu konunun ayrıntılı bilgisine araştırmanın ikonografik çözümleme bölümünde yer verilmektedir. Gelinin bu yolculuk sırasında etrafının bir örtü ya da bir perde ile örtülmesi (Ergun 2010, s.278) de dikkat edilmesi gereken başka bir husustur. Bu uygulamadaki amaç halk arasında; gelinin geldiği yolu görmesinin engellenerek geri dönmesine engel olunması şeklinde açıklanmaktadır. Burada da gerçek dışı ancak mana derinliğine sahip bir anlayışın yattığı anlaşılmaktadır.

Gelin kaldırma adı verilen; kimi zaman gelinin kendi evinde kimi zaman da damadın evine geldikten sonra arkadaşları ve bayan misafirlerin gelini yukarı kaldırmaları uygulaması da göksel nitelikte ulvi bağlantılar taşımaktadır. 'Başı göğe ermek' deyimi ile örtüşen bu uygulama bugün Anadolu'nun farklı köşelerinde "gelin kaldırma" olarak isimlendirilmekte ve sürdürülmektedir. Yine bu uygulamanın yapıldığı bölgelerde gelinin yüksek bir başlık kullanıyor olması da Orta Asya geleneklerinin açık bir uzantısı olduğuna işaret etmektedir.

Koltuklama; topluluklara göre değişen, ağırlıklı olarak damat bazen de gelinin veya damadın yakın akrabaları yada yengeleri tarafindan gerçekleştirilen gelinin attan indirilerek güveyin evine sokulması olayıdır. Bugün hala Anadolu'nun bazı bölgelerinde uygulamasına rastlanmaktadır (Tuna, 2006, s.151).

Türklerde evlenme yani aile kurma, ocak kültü ile doğrudan ilişkili bir kavramdır. Mitler, destanlar, masalsı anlatılar ve yakın tarihli uygulamalarda ocak/ateş ile yuva özellikle de yuvayı kuran gelin figürünü bir arada görmek sıkça karşılaşılan bir durumdur. Bu konuda yazılı ve sözlü kaynaklarda oldukça fazla ögeye ulaşılabilmektedir. Gelin kızın geçeceği yolda belli aralıklarla ateş yakılması, erkeğin evinin önüne gelindiğinde gelinin kilime sarılıp ateş üzerinden geçirildikten sonra içeriye alınması, gelinin damadın evine götürülürken ateş yakılıp üzerinden atlatılması, gelin attan indirilir indirilmez hemen orada hazırlanmıș kül üzerindeki köze bastırılması (Ayva, 2002, s.54), koca evine girdiğinde gelinin ocağın yanına oturtularak saç örgülerinin çözülmesi sırasında gelinin akrabaları tarafindan ocağın üzerine at yağı konması, parlayan alevlerin yükselmesinin uğurlu sayılması, gelinin ocağa üç kez selam vererek 'Bana mutluluk, zenginlik ver! Hayvanlar ver! Donanmış bir ahır, bir oda dolusu çocuk ver!' gibi isteklerden oluşan duası (Ergun, 2010, s.277), gelin ve damadın ilk ateşlerini çakmak taşı kullanarak yakması (Gömeç, 2011, s.51), Türk halklarında bugün dahi kısmen yaşatılan geleneksel uygulamalardandır. Burada amaç, gelinin yeni kuracağı aile ocağına geçmişinden ve varsa günahlarından arınarak girmesi, yeni ocağa sadakatini, saygısını ve aidiyetini göstermesidir. Anlatılan ve yapılagelenlerden özetle; Türklerde ocağın közünün yani sahibinin erkek, ocağa bakan ve besleyenin ise kadın olduğu anlaşılmaktadır.

Türk kültüründe gelinin çeyizi en önemli faktörlerden biridir. Bölgelere ve ekonomik duruma göre değişik boyutlarda olmasına rağmen bugün bile Anadolu'nun her köşesinde geçerli bir olgudur. Bununla birlikte pek çok zaman çeyizle birlikte anılan ve kız çeyizinin kapsamında yeralan ancak hediye olarak sunulan unsurlar da bulunmaktadır. Bunlar da çeyiz gibi temel unsurlar olup dünür ilişkileri açısından oldukça önemli tutulan değerlerdir. Bunlara örnek olarak gelinin kaynanasına hediye etmek için motifli oyalar ile hazırladığı başörtüsü gösterilmektedir. Ergun'un Ataman'dan aktardığına göre; Anadolu Türk

IBAD Sosyal Bilimler Dergisi / IBAD Journal of Social Sciences, (6), Kı̧̧/Winter 2020 
dügünlerinde göğüslük, mitolojik anlamını yitirerek modern bir hal almaya başlamakta, kuşlu taçlarla ve başörtüsünün oya motifleri ile sembolize edilmektedir. Gelinin kaynanasına hediye ettiği, belli motiflerle işlenmiş başörtüsü, düğünde sadece kaynana tarafından kullanılmaktadır. Farklı bölgelerde, Elazığ'da; Çınar, Konya'da; Filize, Aydın'da; Şimşir, İçel'de; Çakırdikeni gibi adlar alan bu mitoloji kökenli oya motifleri, açık-koyu yeşil ağaç ve yaprak motiflerinden oluşmaktadır (Ergun, 2010, s.189,190). Türklerin tabiatla bütünleșik yaşam modelinin bir çıtısı olarak hayat ağacının unsurlarını da içerdiği düşünülen bu oyaların gelin-kaynana, eski-yeni kuşak arasındaki ilişkinin de belirleyicisi olduğu, bu hediyenin verilmemesi durumunda gelin - kaynana kavgalarına varan olumsuzluklara da sebebiyet verdiği bilinmektedir.

Gelinin baba ocağından çıkarken yanında götürdüğü çeyizine ilişkin başka bir örneğe de Ziya Gökalp çalışmalarında yer vermektedir. Doğu Türkistan dügün adetlerinde damat, arkadaşları ile birlikte gelin evine gelmekte, gelinin babası misafirleri karşılayarak damadın boynuna bir yazma dolamakta, daha sonra tefrişatla kızını damadına teslim etmektedir (Gökalp, 1974, s.309). Bu tefrişatın mahiyeti zaman içerisinde ve coğrafyalara göre değişse de genel olarak Türk halklarında gelinin damadın evine eli boş gitmeyişinin ortak gelenek olduğu anlaşılmaktadır. Araştırmanın konusunu oluşturan Çengel / Gelin Habercisi ve benzeri unsurların da bu tefrişatın içinde yer alıp almadığı hususunun araştırılmaya ve açıklanmaya muhtaç bir konu olduğu düşünülmektedir.

\section{2. ÇENGEL: GELIN HABERCISII}

Bugün Anadolu düğün adetleri aynı geçmişte olduğu gibi sayısız çeşitliliğe ve anlam zenginliğine sahip uygulamalarla doludur. Bunların yanısıra uygulamasından vazgeçilmiş ancak sözlü ya da maddi kültürümüzde izleri bulunan bazı adetlerin de yok olmakla var olmak arasında kaldığı görülmektedir. $\mathrm{Bu}$ adetler en azından literatüre geçirilmeyi ve kültür hazinemizde yer edinebilmeyi haketmektedirler. $\mathrm{Bu}$ adetlerden biri sayılabilecek Gaziantep ve Malatya bölgesindeki köylerde hafizalarda kısmen muhafaza edilebilen; "çengel/gelin habercisi" olarak adlandırılan bir unsurdur. Türk mitolojisinin ana karakterlerinden biri olan -kadınların ve çocukların koruyucusu- "Umay Ana", olgusu üzerine yoğunlaşan bu unsur, bu çalışmanın ana materyalini oluşturmaktadır. Üzerinde bulunan ve Türk inanç sistemine göre şekillenen evren tasarımı ile dokuma, nakış, deniz kabukları, sedef düğmeler ve boncuk işleme gibi detaylarla hem geleneksel el sanatlarımıza ışık tutan hem de tasarım alanında ilham verici nitelikte olan bir kültür ögesidir.

Bu çalışmada günümüze ulaşabilmiş, Gaziantep ilinde tespit edilen bir Gelin habercisi / Çengel örneği, mevcut yazılı kaynaklar ve alan araştırmaları sonuçları kullanılarak derleme yöntemi ile malzeme ve ikonografik açıdan analiz edilmeye ve yorumlanmaya çalışılmıştır. (Fot.1.) Bu unsurun Anadolu'da son yüzyılda hazırlanmış ve kullanılmış olabileceği düşünülse de üzerinde Türk mitojisinin binlerce yıllık kültür ve inanç esaslarına ilişkin izler bulunduğu görülmektedir.

Bilindiği üzere, biçime dönüşen düşünceler yapıtları oluşturmakta ve bir yapıtın içinde çoğu zaman birden çok anlam bulunmaktadır. Yapıtın içerisinde saklı olan anlamı kavrayabilmek, yapıtın içeriksel bağlantılarını ve ikonografik değer taşıyan her bir ögesinin kaynağını tespit ederek ortaya çıkarabilmek için bu düşünce yapılarını bilmemiz gerekmektedir. Bununla birlikte incelenen unsurun üretildiği dönem ve etkisinde bulunulan inanç sistemi ile en erken örnekleri hakkında erişilebilen bilginin zenginliği, biçimsel kurgunun etkili bir şekilde yorumlanmasının temel gerekliliğidir. Böylelikle kültür ögeleri doğru analiz edilebilmekte ve pek çok yönü ile yorumlanabilmektedir. 

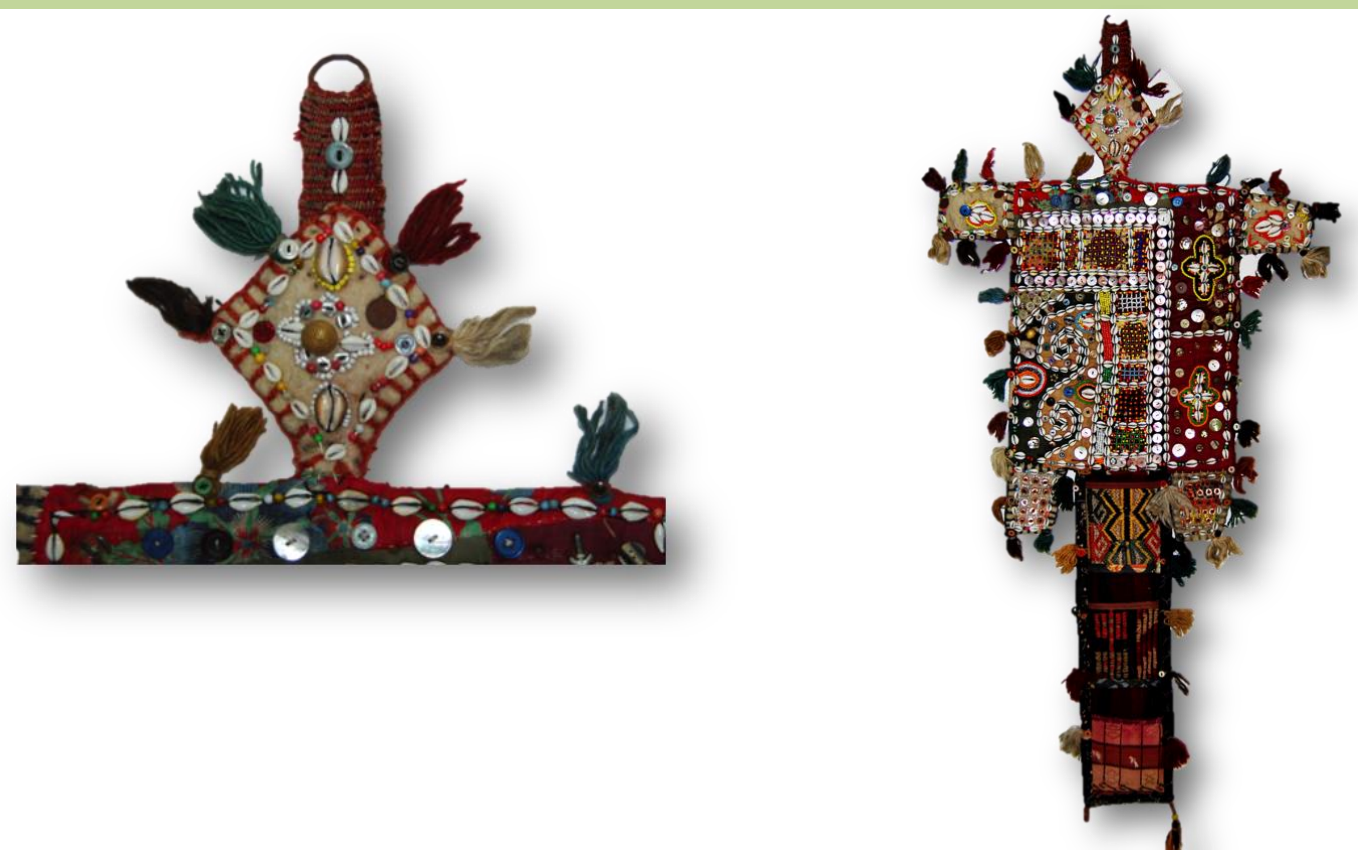

Fot.1- Çengel: Gelin Habercisi. Fotoğraf: Kevser Gürcan Akbaş.

Bu araştırmada Gelin habercisi, Çengel kavramları üzerinde yapılan literatür taramasında Türklerde ve Anadoluda evlenme gelenekleri konusunda yüzün üzerinde kaynak taranmış ancak somut bilgilere ulaşılamamıştır. Bunun Türklerin Asya'dan Anadolu'ya ve hatta Avrupa'ya yolculuklarında konar göçer bir yaşam biçimini benimsemiş olmalarının ve kültür aktarımının yazılı kaynaklardan çok sözlü olarak gerçekleşmesinin sonucu olduğu açıktır. Bu nedenle kültürel değerlerimizin anlaşılmasında hayati önem taşıyan sanat eserlerinin ve günlük/sosyal yaşamda yer bulan bu ve benzeri somut ögelerin ve uygulamaların araştııılması önem taşımaktadır.

Düğün alayının önünde yürüyen bayrak, flama gibi unsurlara bugün hala Anadolu'nun özellikle Ege ve Akdeniz bölgelerinde gerçekleştirilen Türkmen dügünlerinde rastlanmaktadır. Ancak buradaki fark, bu unsurun gelin tarafindan bizzat hazırlanmış olması, gelin alayının geldiğini önceden damat evine haber veren bir araç olarak kullanılması ve dügün sonrasında gelinin çeyizinde yer alarak onun bundan sonraki aile yaşamında koruyucu bir forma dönüşmesidir.

Çengel'e biçim ve uygulama açısından bakıldığında benzer başka bir olgu, "Nahıl" geleneği olarak karşımıza çıkmaktadır. Nahılların özellikle Osmanlı dönemi şenliklerinde yer alması ve bunların minyatürlere de konu olması nedeniyle farklı özellikte ve ebatlarda olanlarına ilişkin bilgilere kaynaklarda rastlanmaktadır. Farklı sözlüklerde tanımlarına yer verilen Nahıl; balmumundan yapılan, yukarı doğru incelen konik formda, üzeri çeşitli malzemelerle süslenmiş bir unsur olup, özellikle evlenme ve sünnet törenlerinde gelinin ya da sünnet çocuğunun önünde taşınmaktadır (Sözen ve Tanyeli, 1992, s.170, Pakalın, 1983, s.642). Bu unsurun daha çok şölenlere zenginlik katmak için kullanıldığı ve onun da Çengel'de görüldüğ̈̈ gibi ekonomik duruma göre şekillendiği anlaşılmaktadır. Osmanlı padişahlarının hayranlık uyandıran ve güç gösterisine dönüşen imparatorluk şölenlerinde Nahılların zengin biçimleriyle boy gösterdikleri, Levni'nin Surnamesindeki minyatürlere yansıyan halleriyle dikkati çekmektedir. Türk halkları arasında hayat ebedilik ve güzellik kavramları ile birlikte yaratılışın kaynağı olarak algılanan Hayat Ağacı kültü ile ilişkilendirilen bu unsur, aynı zamanda evrenin ölümsüzlüğünün sembolü ve yerkürenin de ekseni olarak tanımlanmaktadır (Corsini, 2013, s.51). Hala yaşayan Nahıl ustalarının olduğu düşünüldügünde, Nahılların da biran önce ele alınması ve yaşayan kültürel değerlerimiz arasında tekrar canlandırılması gerekliliği bulunmaktadır. Nahıl ve Çengel yapısal olarak farklılık gösteriyor olsa da birbirlerine ilişkin ip uçlarını içerdikleri gözden kaçırılmamalıdır.

\section{İnsansı Figür / Ruh Atası (Yardımcı - Koruyucu Ruhlar)}

Türklerin tarih öncesi devirlerden itibaren inanç sisteminde yer alan koruyucu, yardımcı ruh anlayışı, zaman zaman çadırların baş köşelerine koydukları ongonlar üzerinde de kendini göstermektedir. Altay bölgesi halklarında ruh kavramı, insan, hayvan, bitki, 1şık, rüzgar, yıldızlar, madenler gibi canlı cansız 
her türlü varlığa hayat veren, görünmeyen kuvveti ifade etmektedir (Roux, 2011, s.165). Şaman giysilerinde bu figür, özellikle ruh atası olgusu ile karşılı̆̆ını bulmaktadır. Şaman giysileri üzerinde metal ya da keçeden hazırlanmış olarak ruh atasını ifade eden figürlere yer verildiği görülmektedir. (Fot. 2) Böyle bir kullanımda bu unsurun ruh atasını simgelemediği ancak koruyucu yardımcı ruhlardan (bu aynı zamanda bu unsurda Umay Ana ile de karşılığını bulabilir) sahibini ve ondan doğacak yavrularını koruyup kollamasının dilendiği anlamına gelebileceği düşünülmektedir.
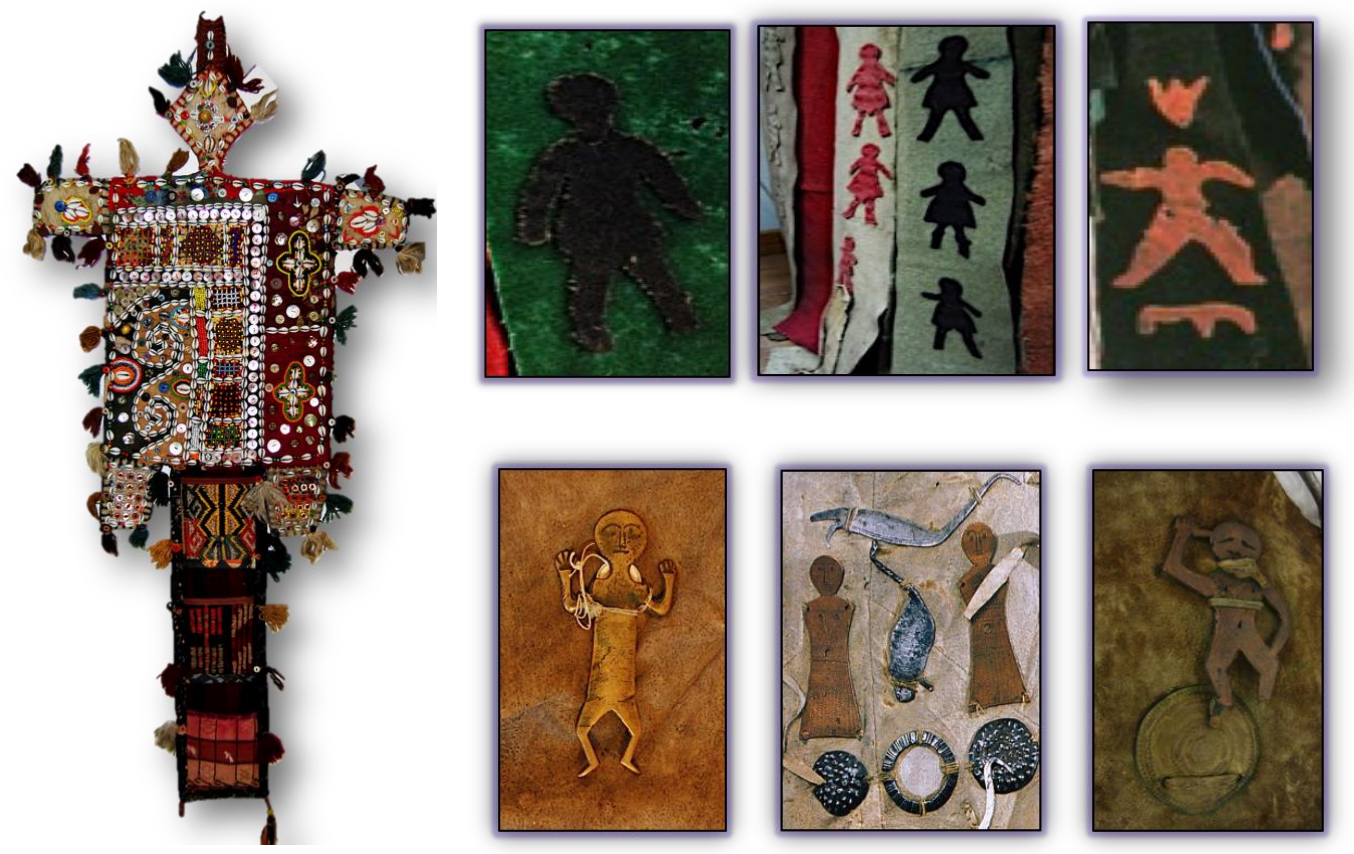

Fot. 2- Keçeden (Hakasya Bölgesi) ve metalden (Yakutistan Bölgesi) hazırlanmış insansı figürler.

Fotoğraf: Kevser Gürcan Akbaş.

Asya ve Sibirya Bölgesi Türk halklarının eski inanç sistemine göre göğün yedi ya da dokuz kat yukarısında ailesi ile birlikte yaşayan Bay Ülgen'in kızlarının bezden yahut metalden hazırlanmış bebek figürlerine de yaşam alanları içerisinde çokça rastlanmaktadır. Ülgen'in kızları genellikle Şaman'ı astral seyahatleri sırasında kötü körmösten korumak için giysisinin üzerinde yer almaktadırlar. Türk halklarında insansı figürler ve bu figürlerle oluşturulmuş nesneler yine çadırların ocak kısımlarında yukarı bir hizada muhafaza edilmekte ve koruyuculuklarına güvenilmektedir. Bu unsurun insansı bir şekil almış olmasının bu olguya da karşılık gelebileceği düşünülmektedir.

\section{Umay Ana (Kadın ve Çocukların Koruyucusu)}

Umay Ana'nın görsel tasvirlerinin yanısıra (Fot. 3) bazı ritüellerin içerisinde de anlam kazandığı görülmektedir. Bunlardan bazılarının; yeryüzüne inişi, bekaret ve yuva hakimiyeti anlamlarına gelen gelinin başına al duvak örtülmesi, güveyin gelin almadan sonraki ilk namazını bu duvak üzerinde kılması, gelinin beline kırmızı kuşak bağlanması, gelinin başına ve duvağına ince teller konarak omuzundan aşağıya sarkıtılması, başına elmas ve oyalarla süslü hotoz takılması, baba evinden damada vermek üzere ayna taşıması, göğsüne kuş kaburgalarını simgeleyen göğüslük takması ile kendini gösterdiği düşünülmektedir (Ergun, 2010, s.278.). Geleneksel ritüellerde baba ocağından ayrılarak koca evine getirilen gelinin, yeni evin eşiğinden sağ ayağını atarak geçmesinin ve diz çöküp üç kez ocağa selam vermesinin ardından içine yağ konmuş olan kabı ateşe boşaltarak ve "Ateş-ana, May (Umay)-ana, şefaat ede gör!" (Yegorov, 1982, s.96) diyerek dua etmesi de Umay Ana figürünün içselleştirilmesinin güzel bir örneği olarak karşımıza çıkmaktadır.

Çocukların ve kadınların koruyucu ruhu olduğuna inanılan Umay Ana, Sibirya ve Altay bölgesinde yaşayan bazı Türk halklarında kaynana-dünür ile de ilişkilendirilmektedir ve Umay Ana'nın yeryüzündeki temsilcisi olduğuna inanılmaktadır. $\mathrm{Bu}$ yüzden düğünde kaynana, boncuk ve sedef düğmelerle süslenmiş bir tören kıyafeti giymektedir. Pogo adı verilen göğüslüğün üzerinde kuşun gögüs 
kafesini simgeleyen nitelikte şekiller bulunmaktadır (Sagalayev, 1991, s.83,108). Farklı bölgelerde değişik uygulamalarda benzer yönüyle karşımıza çıkan kuşun gögüs kafesini simgeleyen șekiller, Şaman inanç sisteminin de ana prensiplerinden birini oluşturmaktadır. Çengel üzerinde de açıkça görülen bu figür, (Fot. 4) Umay Ana'nın kutsallığı ve gökyüzünden kuş suretinde yeryüzüne indiği inancı ile de örtüşmektedir.
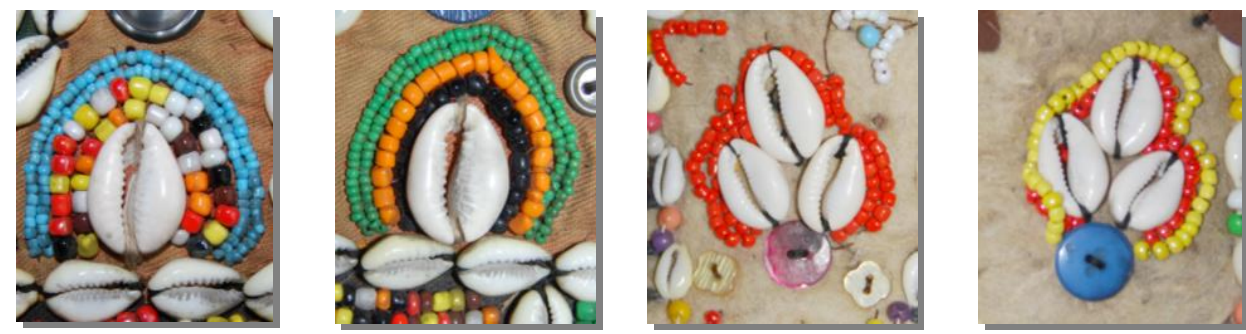

Fot. 3- Çengel. Deniz kabuğu ile oluşturulmuş Umay Ana figürleri. Fotoğraf: Kevser Gürcan Akbaş.
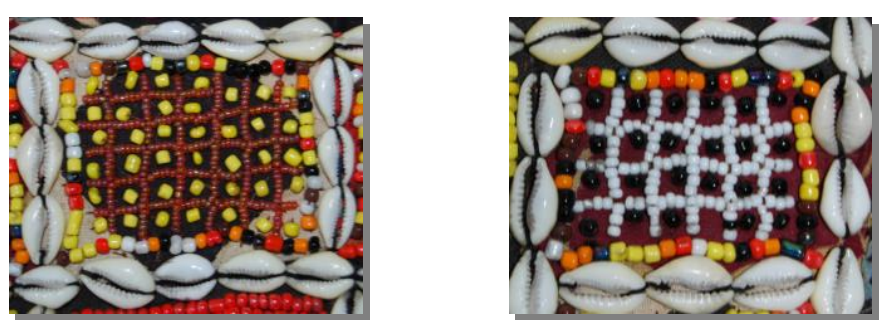

Fot. 4- Çengel. Deniz kabuğu ve boncuklarla oluşturulmuş ızgaralar. Fotoğraf: Kevser Gürcan Akbaş.

Izgaralar, Türk mitolojik sistemi içerisinde yer altına geçiş yollarını simgelemektedirler. Türklerdeki evren anlayışına göre şekillenen bu inanç içerisinde ölüler aleminin yolları her zaman açıktır. Onlarla iletişim kuran klanın Şamanı olsa da ata ruhları akrabalarının koruyuculuğunu üstlenmiş olan karakterlerdir. Şaman bu ızgaraları yerin altına geçiş için kullanmaktadır. Çengel üzerinde geometrik desenler olarak dekoratif bir yapıya bürünmüş olan bu ızgara şekilleri, (Fot. 4) bu unsurun eski Türk Şamanik inanç sistemine yakın bir formda hazırlanmış olduğu göz önünde bulundurulduğunda, anlamca Umay Ana olarak betimlenen kuşun göğüs kafesi kemiklerinin yanısıra başkaca anlamlar da taşıyabileceği ihtimalini ortaya koymaktadır. Şamanik inanç sisteminde bu ızgaralar aynı zamanda kaburga kemiklerini (Şamanın, ruh atasının va yahut da donuna/biçimine büründüğü yardımcı-koruyucu hayvanın) ifade etmekte, bürünülen hayvanın gücünün Şamana aktarımına ve ölüp yeniden dirilmenin sonucu olarak ölümsüzlüğüne gönderme yapmaktadır. Ayrıca küçük karelerden oluşan figürlerin ortasında boncuk detaylarına yer verilmesi, bazı araştırmacılara göre Türk halk inanışlarındaki kutsal suya da işaret etmektedir. Bizans kaynaklarında "Türkler ateşi, suyu ve havayı kutlu görürler, toprağı da mübarek sayarlardı" ifadesine yer verildiği görülmektedir (Mangaltepe, 2009, s.157). Su Türkler için her zaman önemli bir eleman olmuştur. Çünkü yaradılış mitlerinde ifadesini bulan bir anlayışla gökle yer yaratılmadan önce herşeyin su olduğu yeryüzünün ve gökyüzünün bulunmadığına inanılmaktadır (Roux, 211, s.111).

Kompozisyona genel olarak bakıldığında bu kare figürler bir bütün olarak mekan betimlemesi ile de ilişkilendirilebilmektedir. Uzak bir ihtimal gibi görünse de bazı anlatıların halkın duygularına yön verebilmesi, masallarda anlatılan kişi ve mekanların gelecek tasarlamada öykünülecek figürler olması mümkün görülmektedir. Bir anlatıda (Er-Sogotoh destanı) tarif edilen kırk köşeli, kırk pencereli ev, büyük bir salon, üç ocak ve ocakların başlarında oturan kadın figürleri anlatımı ile Çengel'in kompozisyon bütününde görülen benzerlikler oldukça dikkat çekicidir. (Fot. 5)

“... Evi, onun yurdunun üstünde tıpkı mavi bir duman gibi görünüyormuş. Kırk pencereli, kırk kösseli bir evmiş. Her köşsesi gümüşten yapılmış imiş. Evin ortasında büyük bir salon varmış. Bu salonda da ü̧̧ ocak 
bulunur ve her ocă̆ın üstünde de baca tütermiş. Her ocağın başında da birer kadın otururmuş..." (Ögel, 1993, s.105).

Gelin olmaya hazırlanan bir genç kızın kendisini masalsı bir zenginliğe, bolluk ve berekete hazırlamak istemesi ve niyetlerin dua yerine geçeceği düşüncesi ile betimlemeleri görsel bir kompoziyona dönüştürmesi yadsınacak bir durum olmadığından ilişkisinin bulunabileceği düşünülmektedir.

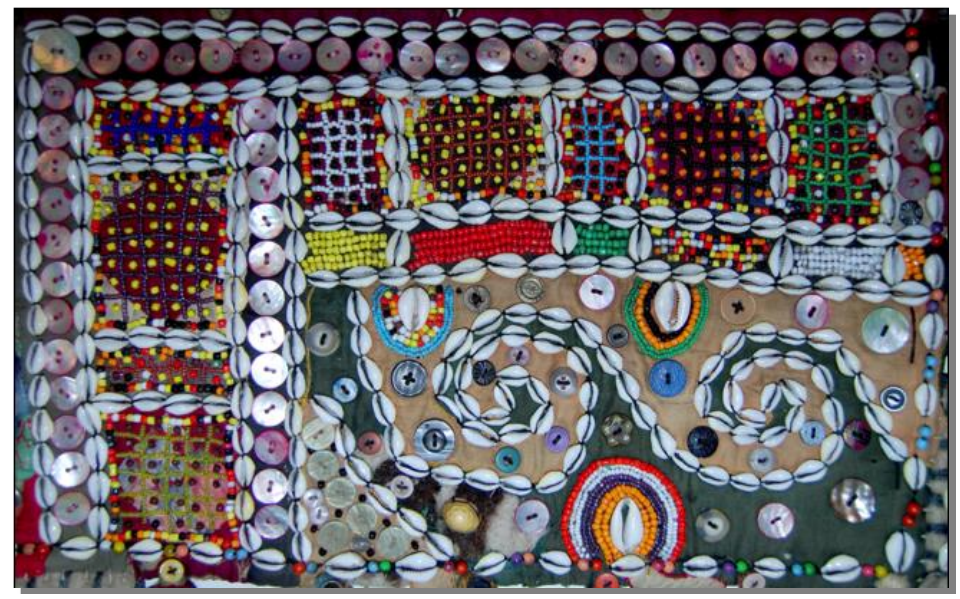

Fot. 5- Çengel (detay). Deniz kabuğu, boncuk ve düğmelerle oluşturulmuş kompozisyon.

Fotoğraf: Kevser Gürcan Akbaş.

Dörtgen ya da kare formların, Orta Asyadaki Türklerin inançları ile İslam ve Bizans çevrelerinde de evrenin sembolü olarak kabul edildiği görülmektedir (Esin 1979, s.13,19, Ögel, 1989, s.95,474). Özellikle baklava şeklindeki kare kullanımın doğu-batı-kuzey-güney olarak dört ana yönün, sonbaharkış-ilkbahar-yaz olarak dört mevsimin, toprak-su-ateş-hava olarak da dört unsurun birleşimiyle evreni temsil ettiği bilinmektedir. Çengel'de kare formların ana gövdeyi oluşturması, ve insansı bir figüre dönüştürülmüş olması, bu unsura mitolojik bir anlam kazandırmaktadır. Bununla birlikte, Çengel üzerinde dört yönü çağrıştıran, süsleme aracı olarak kullanılmış farklı elemanlar da yer almaktadır. (Fot. 6)
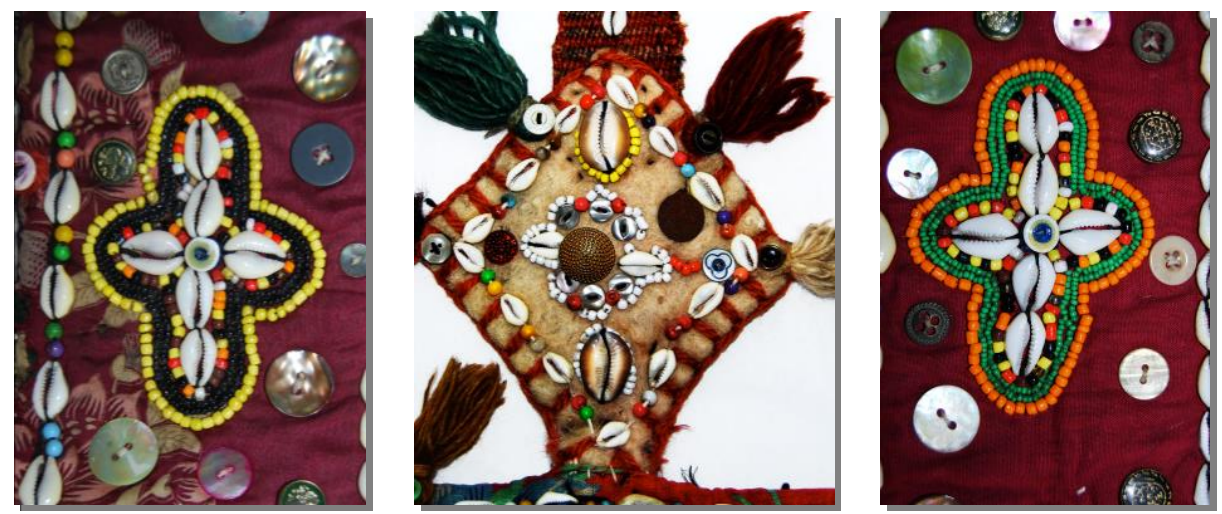

Fot. 6- Çengel (detay). Deniz kabuğu, boncuk ve düğmelerle oluşturulmuş dört yön imgeleri. Fotoğraf: Kevser Gürcan Akbaş.

6 no'lu fotoğrafta görülen düğme, boncuk ve deniz kabuklarıyla oluşturulan formların aynı zamanda göksel unsurları yani yıldızları da simgeliyor olabilecekleri düşünülmektedir. Çünkü Türk halk süslemelerinde sedef düğme ve deniz kabukları ile oluşturulan kompoziyonlarda bu göksel unsurlara sıkça rastlanmaktadır. Bu durum yıldızların Türk kavimlerinde daima önemli bir rol oynamasından kaynaklanmaktadır. Yıldız bilgisi; savaşçı olan ve atlı bir kültüre sahip olan Türkler için her zaman hayati önem taşımaktadır. Çünkü yıldızlar, kervan yolculukları, akınlar, avlanma, tarım gibi aktiviteler için zaman belirleyici ve yol gösterici olarak fayda sağlamaktadır (Gültepe, 2014, s.465). 


\section{Yuvarlak Formlar ve İç İçe Daire Şekilleri}

Çengel üzerinde renkli boncuklarla sıralı olarak iç içe daire formu oluşturan motifler yer almaktadır. $\mathrm{Bu}$ unsurlar tam daire değildirler ancak kompozisyon içinde bulundukları yerler ve renklerin sıralı olarak belli bir düzende yerleştirilmiş olması, bu unsurların hem evrenin katlarına (aşağı - yukarı - orta dünya) hem de evrenin ilahi formuna gönderme yapıyor olabileceği düşünülmektedir. (Fot. 7) İç içe dairesel formlar, birçok kültürde tanrının sembolleri olarak kabul edilmektedir ve büyük bir coğrafyada kabul görmektedir (Karamağaralı, 1993, s.258). İslam metafiziğinde de yaratıcı, insan aklının sınırları dahilinde La-mekan olarak bir küre formundadır ve dairesel figürler göksel konuları ifade etmektedir. İbni Sina Güneş Sistemi'ni kastederek Ay küresine kadar dokuz adet kürenin varlığından ve her kürenin de bir nefsi oluşturduğundan bahsetmektedir. Mevlevîler ve Alevîler başta olmak üzere bazı inanç gruplarında da ibadet sayılan sema, semah ve zikr icralarında daireler çizilmesi, halka oluşturulması ile birlikte İslam felsefesinde yaratıcının halka gibi başı ve sonu olmayan sonsuz nur şeklindeki tasavvurunun benzer zihniyetin ürünü olduğu anlaşılmaktadır (Karamağaralı, 1993, s.269, 260). Sembol niteliği taşıyan bu unsurların eserlerin ve eşyaların üzerine konma nedenlerinin yaygın olarak, sahiplerini şerden korumak, ilahi gücün koruyup kollayıc1, yüceltici gücünden faydalanmak olduğu göze çarpmaktadır.

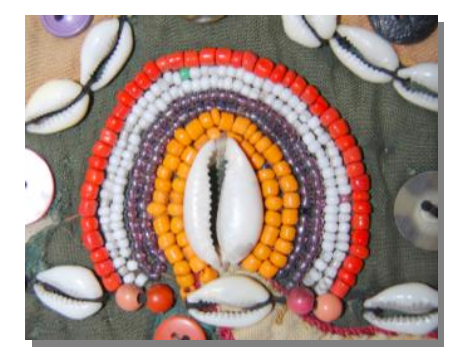

Fot. 7- Çengel (detay). Boncuklarla oluşturulmuş iç içe dairelerden oluşan figür. Fotoğraf: Kevser Gürcan Akbaş.

Türk Mitolojisinde Evrenin Dolambaçlı Yolları

Çengel üzerinde helozonik formların bulunduğu bir bölüm oldukça dikkat çekicidir. (Fot. 8) Deniz kabuklarıyla oluşturulmuş olan bu kısmın zemini, yeşil keçe kumaş ile renklendirilmiş durumdadır. Deniz dalgasına benzeyen bu şekiller, boynuz formunu da andırmaktadır. Ancak bir gelin habercisinin (gelin alayının yola çıktığını haber veren) üzerinde bulunması itibariyle en yakın anlamın dolanılarak gidilen yollar olduğu düşünülmektedir. Türk düğün geleneklerinde gelinin damat evine farklı yollar kullanılarak, bulunulan bölgenin etrafı dolaştırılarak götürülmesi geleneğinin var olduğu bilinmektedir. $\mathrm{Bu}$ adetin benzer bir şekilde bugün bile şehirlerde gerçekleştirilen modern düğünlerde uygulandığ1 görülmektedir. Bu durum pratikte gelinin baba ocağına geri dönüşünün güçleştirilmesi gibi açıklansa da derinlerde farklı anlamlar taşıyabileceği de düşünülmektedir. Katanov anlattığı Hami Şehri Tatarlarının dügün geleneklerinde, gelinin damat evine götürülmesinden evvel delikanlıların ve genç kızların gelini ortalarına alarak söyledikleri maninin bir bölümünde bu yolculuğun özellikle dolaşılarak yapıldığına işaret eden bir bölüm göze çarpmaktadır.

“Acı acı ağlar gelin anası yar yar, Dolambaçlı yoldan bir kız geliyor yar yar” (Katanov, 2004, s.37,38).

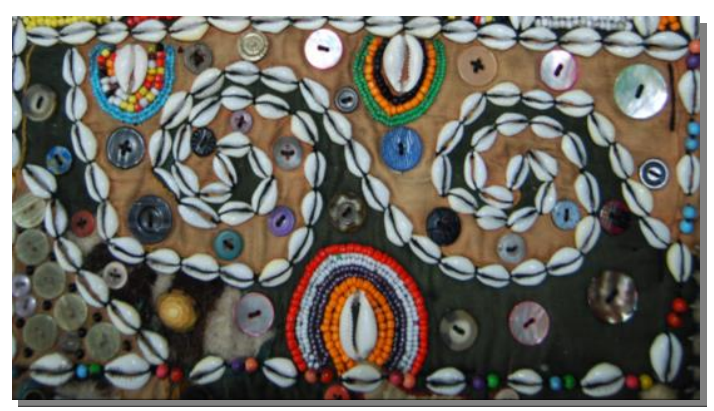

Fot. 8- Çenge (detay). Deniz kabuğu ve düğmelerle oluşturulmuş desen. Fotoğraf: Kevser Gürcan Akbaş. 
Asya ve Sibirya Bölgesi'nde varlık gösteren Şamanlık geleneğinin ana elemanlarından birini oluşturan bazı Șaman elbiselerinde de buna benzer ögeler yer almaktadır. (Fot.9) Şaman inanç sisteminde bu şekiller, Türklerdeki evren anlayışına paralel olarak yer altının zikzag ve dolambaçlı yolları olarak karşılığını bulmaktadır (Gürcan, 2016, s.165). İki kompozisyon arasındaki benzerlik, konunun derinlemesine araştırılması ihtiyacına işaret etmektedir.

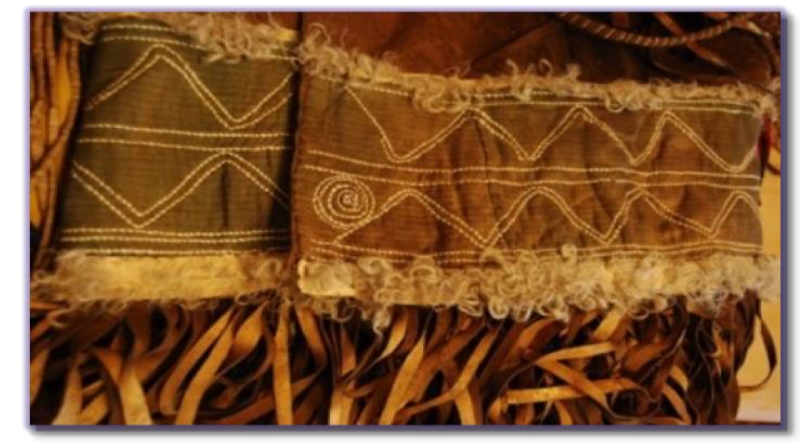

Fot. 9- Karagas/Tofalar Şaman Elbisesi (etek ucu detayl). Rusya Bilimler Akademisi - Kuntskamera Antropoloji ve Etnografya Müzesi. Arşiv No:1480-17. (Fotoğraf Kevser Gürcan Akbaş) (Gürcan, 2016, s.165).

\section{Deniz Kabukları}

Çengel'in üzerinde süsleme için bol miktarda kullanılmış olan deniz kabukları, kökeni milat öncesine dayanan bir malzeme olarak, Türk kültüründe her zaman var olmuş bir unsurdur. Özellikle Altay Bölgesi Şaman elbiselerinin de ana süsleme malzemelerinden biri olduğu görülmektedir. Şaman inanç sistemi üzerine çalışmalar gerçekleştiren araştırmacılar deniz kabuklarının Türk halkları arasında tılsımlı kabul edilen bir unsur olduğundan ve aynı zamanda bu unsurun kadın üreme organı ile de ilişkilendirilerek doğurganlığı dolayısı ile ailenin çoğalması ve bereketi simgelediğinden bahsetmektedirler (Eliade, 1992, s.143).

Deniz salyangozunun kabuğu olan bu doğal unsur, Anadolu'nun farklı bölgelerinde çılkak, peçiç, kesbik, kalaç, dilgöz, yılan başı, bel boncuğu, deve boncuğu, it boncuğu, tazı boncuğu, gibi isimlerle anılmaktadır (Bülent, 2008, s.312).

$\mathrm{Bu}$ unsurların Anadoluda özellikle giysilerin ve aksesuarların yanısıra nazarlıklar üzerinde de bolca kullanıldığı görülmektedir. Anadolu'da yaygın olan nazar inancı; bazı kişilerin kıskanç ve kem gözlü olması ve bakışlarıyla başkalarına zarar verdikleri esasına dayalı bir inanış türüdür. Nazarı önlemek için şimdi bile insanlar özellikle de bebekler, hayvanlar, evler, araçlar vb. birçok yere farklı tiplerde hazırlanmış nazarlıkların asıldığı görülmektedir (Artun, 1996, s.43). Çengel'in kullanılmış olduğu bölge olan Gaziantep bölgesinde geçmişte yaygın olarak oynanan ve hala günümüzde hatırda tutulmaya çalışılan; zar yerine altı tane deniz kabuğunu andıran taşla oynanan peçiç oyununun da bu deniz kabukları ile oynandığı bilinmektedir. Kıymetli etnografya araştırmacısı Sabiha Tansuğ’un Türkmen Giyimi üzerine yaptı̆̆ araştırmalar ve bulgular bize deniz kabuklarının kadın giysileri ve nazarlıklar üzerinde kullnımının eşsiz örneklerine ilişkin bilgiler vermektedir. Tansuğ ayrıca, Türkmen kadın giyimlerinin parçası olan ve kemerbest denilen özel kemerdeki deniz kabuklarıyla yapılmış olan süslemeler üzerindeki topların üç, beş, yedi ve oniki sayılarında tasarlandığını bu toplardan göbek üstünde olanının ortasında üç, kenarlarında oniki deniz kabuğu bulunduğunu, bunların; üçleme ile oniki imamı simgelediklerini bildirmektedir. Diğer topların ortasında bir, kenarlarında beş, yedi ve dokuz adet deniz kabuğu bulunmasının da kutsalı ve kutsal sayıların anlamlarını sembolize ettiğini ifade etmektedir (Tansuğ, 1985, s.13,14). Kaynaklarda buna benzer yaklaşımlar deniz kabuklarının farklı unsurlar üzerlerindeki kullanımları için de görülmektedir. Bu da maddi olarak küçük bir hacime sahip olan deniz kabuklarının geniş Türk coğrafyasında ve engin Türk Kültürü içerisinde oldukça yaygın kullanıldığını ve önemli bir unsur olarak büyük anlamlar ifade ettiğini göstermektedir.

\section{Kırmızı Renk}

Kırmızı, güneşin ve tüm savaş tanrılarının rengi olmakla beraber özellikle ateşi, hükümranlığı, aşkı, gelin 
ve evlilikle ilgili konuları ifade etmektedir. Bu rengin, Türk dünyasında albastı, al ruhu, al karısı formunda hamile ve lohusalara musallat olduğuna inanılan mitolojik karakterle doğrudan ilişkisi bulunmaktadır (Çoruhlu, 2010, s.208). Çengel'in tamamının değil de bir tarafının kırmızı diğer tarafının beyaz (ekru) renkte oluşu, kuzeyde yaşayan Türk halklarının Şamanlarının yarısı kırmızı yarısı beyaz ritüel giysilerini akla getirmektedir. Nagan Şamanı'nın kutsal sayılan giysisinde bulunan bu detay gece ve gündüzü, aydınlığı ve karanlı̆̆ı, yazı ve kışı, iyiliği ve kötülügü temsil etmektedir (Gürcan, 2016, s.287). Çengel üzerinde bulunmasının ardında gelini sonraki aile yaşamı boyunca şerden koruması umulan tılsımlı bir güç oluşturmak düşüncesinin yattığı tahmin edilmektedir.

\section{SONUÇ}

Çalışmanın konusunu oluşturan Çengel/Gelin habercisi üzerindeki unsur ve detayların etraflıca incelenerek tarih öncesi devirlerdeki kültürel oluşumlar, inançlar çerçevesinde değerlendirilmeye muhtaç olduğu görülmektedir. Bu çalışmada titizlikle araştırılmaya ve yorumlanmaya çalışılmış olmasına rağmen bu unsurun pek çok açıdan ele alınarak analiz edilebileceği elbette ortadadır. Ancak bu ve benzeri başlangıç çalışmalarının literatür bilgilerinin gerçek unsurlarla eşleştirilmesi ve kıyaslanması, bu yolla daha sonraki çalışmalara dayanak oluşturması ve 1şık tutması açısından oldukça önemli olduğu düşünülmektedir. Bu unsurun bir sanat eseri olarak değil de işlevselliği de olan maddi ve manevi anlamda bir araç olarak tasarlanmış ve oluşturulmuş olması nedeniyle bölgede kullanılan diğer benzer örneklerden alıntıların yapılmış olması ve kişisel tasarımların da ilave edilmiş olması kaçınılmazdır. Ancak kültürel bütünlük içerisinde şekillenen bu unsurun yine o kültürün değerleri ile analiz edilmesi de bir zorunluluktur.

$\mathrm{Bu}$ geleneksel unsurları hazırlayan kişilerin herbirinin bu derin anlamları bilerek ve kurgulayarak ortaya koymaları elbette beklenmemektedir. Burada etkin olan, toplum hafizasında yer edinmiş inanışların kodlamalarıdır. Böylelikle gün yüzüne çıkabilen bu şifreler, bizim yorum ve değerlendirmelerimize kaynak oluşturabilmektedir. Kültür hazinemize değer katan böylesi doğal, gerçek ve kıymetli unsurlar üzerinde yanlı bir bakış açısı olmadan farklı alanlarda uzmanlaşmış araştırmacıların bilgi birikimlerini ve saha gözlemlerini de esas alarak çözümleme yaklaşımına girmeleri beklenmektedir.

Tespitlerden hareketle bu unsurun açıkça Orta Asya Türk halk kültürünün etkilerini taşıdığı görülmektedir. Orta Asya geleneklerinde evlenme ritüelleri anlatılarında daha çok aktivitelere ve sözlü kültür ögelerine yer verildiğinden gelinin çeyizinde nelerin olduğuna ya da ritüeller sırasında hangi maddi unsurların yer aldığına detaylı olarak yer verilemediği dikkati çekmektedir. Bu nedenle Çengel gibi bir unsur hakkında bilgiye ulaşmak neredeyse mümkün olamamaktadır. Ancak gelin alma olayı ve kız tarafının damat evine gitmesi/götürülmesi ritüellerinde benzeri unsurlardan bahsedildiği görülmektedir. Neyse ki bu ritüeller sırasında gerçekleştirilen aktiviteler ve sözlü kültürümüze yansıyan elemanlar (şiir, mani, vb) bizim bazı bağlantıları kurabilmemize olanak sunmaktadır.

Analizi yapılmaya çalışılan Gelin Habercisi / Çengel; kullanılan motif, malzeme, teknik ve ikonografik açıdan kendi içerisinde tutarlı bir bütünlük oluşturmaktadır. Saf bir halk inancının figürlerinin yer aldığı, tasvirlerin ustaca ve dikkatlice oluşturulduğu kompozisyonda, Türk halk inanışlarının temel unsurlarını içeren birden fazla odak noktası bulunduğu görülmektedir. Bu üslup Türk mitolojisi ve inanç sisteminin çıktılarından olan başta Şaman elbiseleri ve bu inanışa ait aksesuarlar ve materyaller olmak üzere farklı Türk coğrafyalarında şekillenen eserleri çağrıştırmaktadır. Benzer örneklerine bazı müze örneklerinde "nazarlık" olarak rastlansa da bu ebat ve içerikte bir unsurun nazarlık işlevi de görmesinin yanısıra daha fazla mana içerdiği kesindir. Unsur üzerinde bulunan çok sayıda mitolojik eleman, Türk halk inanışlarından oluşan kendi kültürel parametrelerine dikkati çekmektedir. Bu çalışmanın sonunda elde edilen verilerin ve analizlerin farklı alan uzmanları tarafından eleştirel bakış açısıyla değerlendirilmesi beklenmektedir. Zengin kültürel oluşumların tespitine ve doğru olarak belgelendirilmesine katkı sağlamak üzere, bölgenin Türk coğrafyası içerisindeki rolü ve bu rol nedeniyle oluşan ilişkilerin ve etkilenmelerin etraflıca ortaya konulması ümit edilmektedir. Çengel örneği üzerinde yer alan, incelenen ve yorumlanmaya çalışılan detayların moda tasarımcılarına da ilham verici olması, bu yolla yerel değerlerimizin evrensel eserlere dönüşebilmesi konusunda alana katkı sağlaması hedeflenmektedir. 
Bu makale, 23-25 Ağustos 2019 tarihli 2. Uluslararası Mardin Artuklu Bilimsel Araştırmalar Kongresi'nde bildiri olarak sunulmuş ve özet kitabında yayınlanmıştır.

\section{KAYNAKÇA}

Aksoy, M. (2008). Kültür sosyolojisi açısından halı kilim sanatı ve etnografik eserlerdeki damgaların dili. 38. ICANAS Uluslararası Asya ve Kuzey Afrika Çalışmaları Kongresi, C.1. Ankara: Atatürk Kültür, Dil ve Tarih Yüksek Kurumu, 75-120.

Artun, E. (1996). Çukurova yörüklerinin gelenek ve görenekleri. I. Akdeniz Yöresi Türk Toplulukları Sosyo - Kültürel Yapısı (Yörükler) Sempozyum Bildirileri Antalya. Ankara: Kültür Bakanlı̆̆1 Yayınları.

Artun, E. (2005). Halk kültüründe değişimin topluma etkisi ve sonuçları. Halk Kültüründe Değişim Uluslararası Sempozyumu Bildirileri, 57-71.

Aydemir A. (2013). Türk dünyasında bazı düğün terimleri ve 'al duvak' geleneği üzerine. Turkssh Studies, 8(9), 619-655.

Ayva, S. (2002). Türk kültüründe gelinler ve ocak. Anayurttan Atayurda Türk Dünyası Kültür ve Araştırma Dergisi, 23, 48-60.

Bülent, E. (2008). Anadolu amulet geleneğinde ç1kak ve eski kültürlerde izleri. 38. ICANAS Uluslararası Asya ve Kuzey Afrika Çalışmaları Kongresi, C.1 Ankara: Atatürk Kültür, Dil ve Tarih Yüksek Kurumu, 311-328.

Çoruhlu, Y. (2010). Türk mitolojisinin ana hatları. İstanbul: Kabalcı Yayınevi.

Eliade, M. (1992). Imgeler simgeler. Çeviri: Mehmet Ali Kılıçbay. Ankara: Gece Yayınları.

Emen, H. (2015). Gazipaşa'daki geçiş dönemi ve halk hekimliği pratiklerinde orta asya türk kültürü ve inanç sisteminin tesirleri. Türk Dünyası İncelemeleri Dergisi, 15(1), 29-43.

Ergun, P. (2010). Türk kültüründe kavaktan inen gelin motifi. Balıkesir Üniversitesi Sosyal Bilimler Enstitüsü Dergisi, 13(2), 186-195.

Ergun, P. (2010). Türk gelininin mitolojik göçü, Balıkesir Üniversitesi Sosyal Bilimler Enstitüsü Dergisi, 13(24), 275-290.

Esin, E. (1979). Türk kozmolojisi (ilk devir üzerine araştırmalar). İstanbul: Edebiyat Fakültesi Matbaası.

Genç, L. (2018). Rites of passage in Ahmetli village. Doktora Tezi, Yeditepe Ü. Sosyal Bilimler Enstitüsü, İstanbul.

Gennep, A. V. (1960). The Rites of passage. USA: The University of Chicago Press.

Gökalp, Z. (1974). Türk medeniyeti tarihi 2. İstanbul: Türk Kültürü Yayını.

Gömeç, S. (2011). Şamanizm ve eski türk dini. Ankara: Berikan Yayınevi.

Gömeç, S. (1998). Şamanizm ve eski türk dini, shamanism and old turkısh religion. Pamukkale Üniversitesi Eğitim Fakültesi Dergisi, 4, 38-50.

Gültepe, N. (2014). Türk mitolojisi. İstanbul: RESSE Yayınları.

Gürcan, K. (2016). Kutsal şaman elbiseleri. İstanbul: Ötüken Yayınevi.

Karamağaralı, B. (1993). İçiçe daire motiflerinin mahiyeti hakkında. Sanat Tarihinde İkonografik Araştırmalar, Hacettepe Ü. Arkeoloji ve Sanat Tarihi Bölümü Sanat Tarihi A.B.D. Ankara: Bizim Büro Basımevi, 249-270.

Katanov, N. F. (2004). Türk kabileleri arasında. Çev. Attila Bağcı. Konya: Kömen Yayınları.

Mangaltepe, İ. (2009). Bizans kaynaklarında Türkler. İstanbul: Selenge Yayınları. 
Mucchielli, A. (1991). Zihniyetler L'es mentalities. Çev. A. Kotil. İstanbul: İletişim Yayınları. Ögel, B. (1993). Türk mitolojisi I. Ankara: Türk Tarih Kurumu.

Öngen Corsini, D.E. (2013). Osmanlı saray şenliklerinden günümüze bir kültür ürünü: Nahıl. Yedi: Sanat, Tasartm ve Bilim Dergisi, 10, 49-57.

Pakalın, M. Z. (1983). Osmanlı tarih deyimleri ve terimleri sözlüğü 2, İstanbul: Milli Eğitim Basımevi.

Roux, J.P. (2011). Türklerin ve Moğolların eski dini. İstanbul: Kabalcı Yayınevi.

Sagaleyev, A. (1988). Traditsionnoe mirovozzrenie tyurkov yujnoy sibiri. Rusya: Novosibirsk.

Sözen, M. ve Tanyeli U. (1992). Sanat kavram ve terimleri sözlüğü. İstanbul: Remzi Kitabevi.

Tansuğ, S. (1985). Türkmen giyimi. İstanbul: Akbank Yayınları.

Tuna, S. (2006). Türk dünyasındaki dügünlerde koltuklama ve kırmızı kuşak bağlama geleneği. Bilig, $38,149-160$. 